\title{
Variation of some chemical and functional properties of Bambara groundnut (Voandzeia Subterranean L. Thouars) during sort time storage
}

\author{
Augustin GOUDOUM ${ }^{1 *}$, Léonard Simon NGAMO TINKEU², Chantal MADOU², Watching DJAKISSAM², \\ Carl Moses MBOFUNG ${ }^{3}$
}

\begin{abstract}
The storage susceptibility of Bambara groundnut (B. G.) (Voandzeia Subterranean (L.) Thouars) to Callosobruchus maculatus and chemical and functional properties of 11 varieties form Far-North of Cameroon were investigate using standard analytical methods. Storage susceptibility shown that, after five months within treatment, C. maculatus destroy 10 to $50 \%$ of grains. The chemical characteristics of none attack grains of 11 varieties were range to 18.64 at $21.08 \%, 6.85$ at $7.44 \%, 49.75$ at $52.68 \%$ and to 6.05 at $7.55 \%$ respectively for protein, fat, starch and free carbohydrate. These chemical characteristics significantly $(\mathrm{p}<0.05)$ decreases form attacks varieties. For the functional parameters, the none attacks grains was range of 130 at $135 \%$, 19.15 at $20.91 \%, 18.20$ at $21.13 \%, 2.76$ at $3.21 \%$ and of 8.54 at $10.14 \%$ respectively for water capacity absorption, solubility index, gel length, ash and humidity. The results of this study indicated that storage susceptibility, chemical and functional properties of B. G. be dependant to the varieties.
\end{abstract}

Keywords: Bambara groundnuts; chemical composition; functional properties; storage susceptibility; callosobruchus maculatus.

Practical Application: Valorisation of the best varieties of Bambara groundnut form Far-North of Cameroon.

\section{Introduction}

Bambara groundnut (Voandzeia Subterranean (L.) Thouars) is an indigenous African crop that is now grown across the continent from Senegal to Kenya and from the Sahara to South Africa (Atiku et al., 2004). As the shortage of food continues to be a major problem of Africa, these legumes are being promoted more than before in order to help in combating malnutrition (Okafor \& Nwabuko, 2003). The affordability of plant protein sources relative to that of animal origins has led to the intensified development of legume processing as a means of enhancing the availability, palatability and diversity of leguminous source of dietary protein. The seeds grow readily in all types of soil and have been described as poor man's crop (Barimalaa et al., 1994). Studies had revealed the detailed nutritional composition to be $16 \%$ crude protein, $9.7 \%$ moisture, $5.9 \%$ crude fat, $2.9 \%$ ash and $64.9 \%$ total carbohydrate (Aremu et al., 2006). It contains an appreciable amount of lysine and a minimum amount of trypsin and chymotrypsin as reported by Olanipekun et al. (2012).

Bambara groundnut is important to smallholders and their households because the beans are an important source of food security, being nutritious and high in protein in Africa and precisely in Northern Cameroon. Because, malnutrition contributes directly or indirectly to more than $60 \%$ of the then million child deaths each year (World Health Organization, 2002; Ijarotimi et al., 2009). The prevalence of malnutrition increases dramatically from the age of 6 to 18 months as a result of poor feeding practices and low purchasing power that characterized many homes. Diets of developing countries are frequently deficient in macronutrients (protein, carbohydrates and fat), micronutrients or both (Brabin \& Coulter, 2003). Although, in common with other legumes, Bambara is deficient in sulphur-containing amino acids (Azam-Ali et al., 2001; Mayes et al., 2012), some genotypes contain higher amounts of methionine and lysine than is found in other legumes (National Research Council, 2006; Kahane et al., 2013). Bambara groundnut is known to come in a variety of colors. Preliminary studies have identified more than eleven varieties of Far-North of the country (Ngamo et al., 2016). However, Chukwujindu et al. (2013) shown that the attributes like grain sources and coat color can contribute to the susceptibility of grains storage pests, and of cost to the nutritional value and chemical composition. Bambara groundnut it is cultivated throughout the north of Cameroon, and it is one of under valorized legumes. One of the main reasons for the low quantity of Bambara groundnuts in the consumer basket is the important loss observed in the culture and especially during postharvest storage (Kellouche \& Soltan, 2004; Ayamdoo et al., 2013). Insects are major pests which qualitatively and quantitatively degrade these seeds during storage (Costa et al., 2006). Calossobruchus maculatus are the 
main pest of Bambara groundnut during storage, capable of destroying an entire stock before the expected storage period.

Give the diversity of its varieties, chemical and food compositions depend greatly. This can predispose grains to storage pests. This present research seeks to obtain baseline information on storage susceptibility to C. maculatus and to determine the proximate physicochemical characteristics and functional properties of 11 Bambara groundnut varieties from Far-North of Cameroon after five months storage in the aim to valorize the best one.

\section{Materials and methods}

\subsection{Insects rearing}

A culture of C. maculatus adults used for study was obtained from naturally infested stores Bambara groundnut. The culture was maintained and reared in the laboratory $\left(31.48 \pm 2.88^{\circ} \mathrm{C}\right.$ and $58.56 \pm 6.78 \%$ relative humidity) on the dry Bambara groundnut in the breeding bottle covered with pieced of muslin cloth. The muslin cloths were held in place with a rubber band to allow good aeration and to prevent the escape of insects. Insects were placed at 25 couples in one-liter jars containing $1 \mathrm{~kg}$ of untreated Bambara groundnut brought at the Maroua-Kodek market. This phase lasted for 30 days to allow the emergence of new adults. After this operation, the Bambara groundnut contained in the different jars were screened; adult weevils were removed and breeding continued with eggs infested Bambara groundnut. This second phase lasted 30 days and 3 days emergence insects were used to infest Bambara groundnut of different treatments.

\subsection{Collection of Bambara groundnut samples and observation}

Bambara groundnut samples were obtained from Maroua-Kodek marked in the Far-North region of Cameroon, during a prospection. Different Bambara groundnut grain lots with four distinct colors or mix color: red, brown, black, and cream-colored were collected for these marked. Eleven varieties sample based on morphological descriptors (shape, color, shape and color of the hilum, ...) as described by Ngamo et al. (2016) have been put in $100 \mathrm{~g}$ batches of $500 \mathrm{ml}$ glass jars capacities closed by ventilated lids. Before storage, Bambara groundnut grains were stored for 7 days at $4{ }^{\circ} \mathrm{C}$, at the end to eliminate any form of insects. Inside each batch, grain sample was infested with 10 Callosobruchus maculatus (5 female and 5 males). Three repetitions of each variety are made.

The constituted pots were stored for 5 months at $35.38 \pm 3.56^{\circ} \mathrm{C}$ and $58.78 \pm 4.08 \%$ relative humidity. After 5 months of storage, the grains were sieved using a Xinxiang Tongxin made sieves with $3 \mathrm{~mm}$ diameters and weight per batch was obtained using a Kern made balance (precision 1/1000 g).

\subsection{Chemical and functional analysis of Bambara groundnut parameters before and after storage}

The chemical characteristics and functional properties analyzes were conducted before and after 5 months of storage to the uninfected and infected Bambara groundnut. The grains were reduced to flour before analysis.

\subsection{Proportioning of Bambara groundnuts starch}

The proportioning of starch was carried out using the method described by Ewers modified (International Bureau for Analytical Studies, 1978). With regard to the infested Bambara groundnut samples, the percentage of starch contained in bore flour produced according to the dry matter at the period of insects attacks were evaluated and removed from the starch value of concerned sample. Hence the quantity of starch contained in attacks grains will be expressed by the formula describe by Goudoum et al. (2012).

\subsection{Proteins}

The protein content was given according to the Kjeldahl method of the total nitrogen determination (Association of Official Analytical Chemists, 1990).

\subsection{Lipids}

The evaluation of oxidation state was made according to the AOAC method (Association of Official Analytical Chemists, 2000).

\subsection{Sugars}

Sugars were extracted and proportioned by Fischer \& Stein method (Fisher \& Stein, 1961).

\subsection{Water absorption capacity}

The determination of the water absorption capacity was performed by the method of Adebowale et al. (2005).

\subsection{Solubility index}

The solubility index (IS) in water is calculated using the Anderson et al. method. (Anderson et al., 1969).

\subsection{Gel length}

The gel length was determined by the method developed by Cagampang et al. (1973).

\subsection{Ash content}

Ash content was determined by AOAC (Association of Official Analytical Chemists, 2000) method.

\subsection{Moisture}

The hot air oven method, AOAC (Association of Official Analytical Chemists, 2000) was used for moisture determination. The samples were dried in a hot air oven (Memmert) at $130{ }^{\circ} \mathrm{C}$ for $1 \mathrm{~h}$ to constant weights.

\subsection{Statistical analysis}

The results obtained from the evaluation of chemical characteristics and functional properties of Bambara groundnut grains during storage were analyzed with analysis of variance 
(ANOVA) using the software Xlstat 2014. The average values were classified using Duncan Multiple Test with the same software.

\section{Results and discussion}

\subsection{Analysis of the attack rate of Bambara groundnuts}

It appears from the Table 1 that unprotected and infected Bambara groundnut grains are subjected to the action of insects with a significant rate $(\mathrm{p}<0.01)$ between different varieties. CM / EN / DW / 07 variety is the most attacked (49.3\%) followed by CM / EN / DW / 03 (40.19\%), CM / EN / DW / 01 (39.5\%) and CM / EN / DW / 27 (37.66\%). Other varieties have an attack rate which is around $10 \%$. Regarding the colors, it appears from this study that Bambara groundnuts having a light color are most damaged by C. maculatus attack.

These result show sufficiently that attack of Bambara groundnut grains starts in the field and continues to storage where serious damage on the nutritional and agronomic quality is found. If no treatment is envisaged, the stock of Bambara groundnut will be destroyed in less than five months of storage (Ngamo et al., 2016). C. maculatus is the main pest, causing quantitative and qualitative damages to this legume. The greater voracity of C. maculatus was reported on several studies. Amevoin et al. (2005). The color of the grain can influence sensibility of C. maculatus. Chukwujindu et al. (2013) report that, other attributes of seeds such as size, nutritional value, chemical composition and coat color are known to affect their resistance to insect attacks and contribute to the susceptibility of grains to the storage pests. These same authors shown that grains source and color affected oviposition and adult emergence counts of C. maculatus.

\subsection{Chemical composition of Bambara groundnuts before and after storage}

The results of proximate chemical composition of Bambara groundnut are shown in Table 2. The result shows that protein, lipid, starch and carbohydrate varied with the storage period and varieties. The protein content also decreased significantly $(\mathrm{p}<0.05)$ during storage of Bambara groundnut. The higher reduction of protein was observed with $\mathrm{CM} / \mathrm{EN} / \mathrm{DW} / 01$ for which protein pass to $21.08 \%$ for uninfected grain at $18.01 \%$ for infected grain five months after. The fat content decreased after five months of storage. The fat content ranged from 6.62 to $6.35 \%$ for the higher variety contents after insects attacks (five month storage). The starch decreased significantly $(\mathrm{p}<0.05)$ like a protein and lipid. The higher reduction of starch was observed with CM/EN/DW/07 for which starch passes of 52.07 for the uninfected grains at $44.26 \%$ for the infected one after five months, follow by the CM/EN/DW/03. For the sugar, any significant different $(\mathrm{p}>0.05)$ was observed between the Bambara groundnut varieties and storage period.

C. maculatus in the environment depreciated qualitatively grains leading to a starch loss as drilling flour. The study of Park et al. (2008) on millet shown that the percentage of starch of treated was high than attacks grains, but less than that described by FAO (Food and Agriculture Organization of the United Nations, 1993) on traditional variety. Beti et al. (1995) showed that the reduction of the rate of oxidation of fatty acids is mainly due to the metabolic activity of insects, which would result in the acceleration of the loss of unsaturated fatty acids which do not support any temperature rise. This is explained by the fact that the infection increases the contact area for oxygen. Similar results of Bambara groundnut were detected by Chiwendu (2007), Yusuf et al. (2008) and Eltayeb et al. (2011) who showed that fat, protein, starch and free sugar were 6.0 to $7.3,17.40$ to $22.36,53.1$ to 55.65 and 6.5 to 8.0 , respectively.

\subsection{Functional properties of Bambara groundnut}

The results of proximate functional properties of Bambara groundnut are shown in Table 3. The result shows that capacity for water absorption (WCA), solubility index (SI) and gel length (GL) varied for the storage period and varieties. The WCA decreased significantly $(\mathrm{p}<0.05)$ during storage of Bambara groundnuts for all the varieties except CM/EN/DW/14 for which any difference ( $p>0.05)$ was observed for the uninfected and infected grains. The SI also decreased after five months storage. The SI ranged from 20.62 to $17.82 \%$ for the higher varieties after five months storage. The GL decreased significantly $(\mathrm{p}<0.05)$ like a WAC and SI, except for the CM/EN/DW/14, $\mathrm{CM} / \mathrm{EN} / \mathrm{DW} / 09, \mathrm{CM} / \mathrm{EN} / \mathrm{DW} / 28$ and $\mathrm{CM} / \mathrm{EN} / \mathrm{DW} / 32$ varieties for which any significant difference $(\mathrm{p}>0.05)$ were observed

Table 1. Evaluation of Bambara groundnut attacks rate after five months of conservation.

\begin{tabular}{lccc}
\hline \multicolumn{1}{c}{ Color } & Size & Varieties & Attack rates (\%) \\
\hline Red & Small & $\mathrm{CM} / \mathrm{EN} / \mathrm{DW} / 14$ & $11.68 \pm 1.77 \mathrm{c}$ \\
Black with brown spots & Normal & $\mathrm{CM} / \mathrm{EN} / \mathrm{DW} / 09$ & $10.44 \pm 1.41 \mathrm{c}$ \\
Black & Small & $\mathrm{CM} / \mathrm{EN} / \mathrm{DW} / 28$ & $12.95 \pm 2.06 \mathrm{c}$ \\
Red with black spots & Small & $\mathrm{CM} / \mathrm{EN} / \mathrm{DW} / 32$ & $9.78 \pm 1.40 \mathrm{c}$ \\
Brown with black spots & Normal & $\mathrm{CM} / \mathrm{EN} / \mathrm{DW} / 21$ & $12.79 \pm 1.53 \mathrm{c}$ \\
Cream (petit) & Small & $\mathrm{CM} / \mathrm{EN} / \mathrm{DW} / 03$ & $40.19 \pm 2.63 \mathrm{~b}$ \\
Brown and cream & Normal & $\mathrm{CM} / \mathrm{EN} / \mathrm{DW} / 20$ & $13.12 \pm 2.10 \mathrm{c}$ \\
Light Brown & Normal & $\mathrm{CM} / \mathrm{EN} / \mathrm{DW} / 12$ & $9.95 \pm 1.49 \mathrm{c}$ \\
Light brown sorted brown & Small & $\mathrm{CM} / \mathrm{EN} / \mathrm{DW} / 27$ & $37.66 \pm 2.04 \mathrm{~b}$ \\
Cream with brown spots & Small & $\mathrm{CM} / \mathrm{EN} / \mathrm{DW} / 07$ & $49.3 \pm 1.82 \mathrm{a}$ \\
Cream & Normal & $\mathrm{CM} / \mathrm{EN} / \mathrm{DW} / 01$ & $39.5 \pm 3.77 \mathrm{~b}$ \\
\hline
\end{tabular}

Averages followed by the same letter in the same column are not different significantly with $\mathrm{P}<0.05$ (Test of Duncan). 
Goudoum et al.

Table 2. Evaluation of some chemical characteristics of uninfected and infected Bambara groundnut after five months storage

\begin{tabular}{|c|c|c|c|c|c|c|c|c|}
\hline \multirow{2}{*}{ Varieties } & \multicolumn{2}{|c|}{ Protein } & \multicolumn{2}{|c|}{ Fat } & \multicolumn{2}{|c|}{ Starch } & \multicolumn{2}{|c|}{ Free carbohydrate } \\
\hline & Uninfected & Infected & Uninfected & Infected & Uninfected & Infected & Uninfected & Infected \\
\hline $\mathrm{CM} / \mathrm{EN} / \mathrm{DW} / 14$ & $18.64 \pm 2.15 b$ & $17.12 \pm 2.65 b$ & $6.85 \pm 1.34 \mathrm{a}$ & $6.33 \pm 3.12 \mathrm{a}$ & $49.75 \pm 4.65 \mathrm{a}$ & $45.01 \pm 4.35 c$ & $6.05 \pm 1.75 a$ & $5.86 \pm 2.15 \mathrm{a}$ \\
\hline CM/EN/DW/09 & $19.1 \pm 3.12 \mathrm{a}$ & $17.05 \pm 2.41 \mathrm{~b}$ & $7.08 \pm 1.81 \mathrm{a}$ & $6.81 \pm 2.45 \mathrm{a}$ & $50.86 \pm 3.75 a$ & $46.32 \pm 4.66 \mathrm{~b}$ & $6.58 \pm 1.75 \mathrm{a}$ & $6.33 \pm 1.84 \mathrm{a}$ \\
\hline $\mathrm{CM} / \mathrm{EN} / \mathrm{DW} / 28$ & $18.92 \pm 2.75 b$ & $17.55 \pm 3.21 b$ & $7.32 \pm 1.68 \mathrm{a}$ & $6.91 \pm 2.55 \mathrm{a}$ & $52.68 \pm 2.41 \mathrm{a}$ & $46.66 \pm 3.78 b$ & $7.31 \pm 2.01 \mathrm{a}$ & $7.22 \pm 1.77 \mathrm{a}$ \\
\hline $\mathrm{CM} / \mathrm{EN} / \mathrm{DW} / 32$ & $19.58 \pm 3.56 \mathrm{a}$ & $17.51 \pm 2.33 b$ & $7.51 \pm 1.86 \mathrm{a}$ & $7.44 \pm 1.86 \mathrm{a}$ & $51.56 \pm 3.86 \mathrm{a}$ & $47.26 \pm 2.48 b$ & $7.25 \pm 1.94 \mathrm{a}$ & $7.23 \pm 1.86 \mathrm{a}$ \\
\hline $\mathrm{CM} / \mathrm{EN} / \mathrm{DW} / 21$ & $19.3 \pm 1.84 \mathrm{a}$ & $17.02 \pm 2.47 \mathrm{~b}$ & $7.62 \pm 1.77 \mathrm{a}$ & $6.94 \pm 2.15 \mathrm{a}$ & $50.14 \pm 2.15 \mathrm{a}$ & $47.1 \pm 2.84 \mathrm{~b}$ & $7.05 \pm 1.76 \mathrm{a}$ & $7.01 \pm 2.07 \mathrm{a}$ \\
\hline $\mathrm{CM} / \mathrm{EN} / \mathrm{DW} / 03$ & $20.83 \pm 1.02 \mathrm{a}$ & $18.89 \pm 2.65 b$ & $8.35 \pm 1.24 \mathrm{a}$ & $6.54 \pm 2.45 b$ & $52.05 \pm 4.91 \mathrm{a}$ & $44.92 \pm 2.9 c$ & $7.06 \pm 2.04 \mathrm{a}$ & $6.21 \pm 2.45 \mathrm{a}$ \\
\hline $\mathrm{CM} / \mathrm{EN} / \mathrm{DW} / 20$ & $19.06 \pm 2.14 \mathrm{a}$ & $17.22 \pm 2.65 b$ & $7.25 \pm 1.32 \mathrm{a}$ & $7.01 \pm 1.92 \mathrm{a}$ & $51.23 \pm 3.75 \mathrm{a}$ & $46.31 \pm 3.12 b$ & $7.55 \pm 1.86 a$ & $7.24 \pm 1.64 \mathrm{a}$ \\
\hline $\mathrm{CM} / \mathrm{EN} / \mathrm{DW} / 12$ & $20.65 \pm 1.63 a$ & $17.52 \pm 2.84 \mathrm{~b}$ & $7.35 \pm 1.88 \mathrm{a}$ & $7.31 \pm 2.08 \mathrm{a}$ & $50.77 \pm 5.16 \mathrm{a}$ & $46.05 \pm 2.75 b$ & $7.34 \pm 1.84 \mathrm{a}$ & $7.18 \pm 1.78 \mathrm{a}$ \\
\hline $\mathrm{CM} / \mathrm{EN} / \mathrm{DW} / 27$ & $20.19 \pm 1.47 \mathrm{a}$ & $18.18 \pm 2.47 \mathrm{~b}$ & $7.82 \pm 1.64 \mathrm{a}$ & $6.48 \pm 2.37 b$ & $50.84 \pm 4.75 \mathrm{a}$ & $45.88 \pm 3.45 c$ & $7.42 \pm 1.75 a$ & $7.08 \pm 2.05 \mathrm{a}$ \\
\hline CM/EN/DW/07 & $19.75 \pm 2.05 a$ & $16.71 \pm 2.31 b$ & $8.62 \pm 1.51 \mathrm{a}$ & $6.35 \pm 2.45 b$ & $52.07 \pm 3.76 a$ & $44.26 \pm 3.78 \mathrm{c}$ & $7.51 \pm 2.08 \mathrm{a}$ & $6.88 \pm 3.15 \mathrm{a}$ \\
\hline CM/EN/DW/01 & $21.08 \pm 1.07 \mathrm{a}$ & $18.01 \pm 2.61 b$ & $8.3 \pm 1.72 \mathrm{a}$ & $6.7 \pm 2.86 \mathrm{~b}$ & $51.86 \pm 4.51 \mathrm{a}$ & $45.05 \pm 3.45 c$ & $7.1 \pm 2.61 \mathrm{a}$ & $6.52 \pm 2.86 \mathrm{a}$ \\
\hline
\end{tabular}

Averages followed by the same letter in the same column are not different significantly with $\mathrm{P}<0.05$ (Test of Duncan).

Table 3. Evaluation of some functional properties of uninfected and infected Bambara groundnuts after five months storage.

\begin{tabular}{|c|c|c|c|c|c|c|c|c|c|c|}
\hline \multirow{2}{*}{ Varieties } & \multicolumn{2}{|c|}{ Water absorption capacity } & \multicolumn{2}{|c|}{ Solubility index } & \multicolumn{2}{|c|}{ Gel length } & \multicolumn{2}{|c|}{ Ash } & \multicolumn{2}{|c|}{ Humidity } \\
\hline & Uninfected & Infected & Uninfected & Infected & Uninfected & Infected & Uninfected & Infected & Uninfected & Infected \\
\hline $\mathrm{CM} / \mathrm{EN} / \mathrm{DW} / 14$ & $130 \pm$ & ba & $.15 \pm 2.45 \mathrm{a}$ & $\mathrm{a}$ & $2.45 \mathrm{a}$ & $34 \mathrm{a}$ & $0.86 \mathrm{a}$ & $8 \mathrm{a}$ & $2.14 \mathrm{a}$ & $62 \mathrm{a}$ \\
\hline CM/EN/DW/09 & $132.5 \pm 3.45 a$ & $129.23 \pm 3.25 b$ & $.1 \pm 1.88 \mathrm{a}$ & $17.89 \pm 2.54 b$ & $19.85 \pm 2.07 \mathrm{a}$ & $3.56 \pm 1.45 \mathrm{a}$ & $3.01 \pm 0.45 \mathrm{a}$ & $3.12 \pm 0.47 \mathrm{a}$ & $8.54 \pm 2.18 \mathrm{a}$ & $9.64 \pm 1.86 a$ \\
\hline $\mathrm{CM} / \mathrm{EN} / \mathrm{DW} / 28$ & $131.35 \pm 4.61 \mathrm{a}$ & $129.47 \pm 4.15 b$ & $20.35 \pm 1.62 \mathrm{a}$ & $19.24 \pm 1.64 a$ & $20.12 \pm 1.94 a$ & $19.02 \pm 2.00 \mathrm{a}$ & $2.94 \pm 1.32 \mathrm{a}$ & $3.01 \pm 0.62 \mathrm{a}$ & $9.84 \pm 1.37 \mathrm{a}$ & $10.21 \pm 1.21 \mathrm{a}$ \\
\hline $\mathrm{CM} / \mathrm{EN} / \mathrm{DW} / 32$ & $132.08 \pm 3.45 \mathrm{a}$ & $132.01 \pm 3.15 \mathrm{a}$ & $20.14 \pm 1.42 \mathrm{a}$ & $19.23 \pm$ & $20 \pm 1.65 a$ & $19.54 \pm 1.26 \mathrm{a}$ & $3.14 \pm 0.92 \mathrm{a}$ & $3 \pm$ & $8.62 \pm 1.66 a$ & $.25 \mathrm{a}$ \\
\hline $\mathrm{CM} / \mathrm{EN} / \mathrm{DW} / 21$ & $135 \pm 2.08 \mathrm{a}$ & $131.1 \pm 4.17 \mathrm{~b}$ & $20.91 \pm 1.96 a$ & $18.91 \pm 1.88 \mathrm{~b}$ & $20.31 \pm 1.68 \mathrm{a}$ & $17.65 \pm 1.58 b$ & $2.93 \pm 1.94 a$ & $3.14 \pm 0.62 \mathrm{a}$ & $8.54 \pm 1.86 a$ & $.85 a$ \\
\hline $\mathrm{CM} / \mathrm{EN} / \mathrm{DW} / 03$ & $133.56 \pm 3.14 a$ & $128.91 \pm 3.15 b$ & $20.55 \pm 1.75 \mathrm{a}$ & $17.41 \pm 1$ & $20.11 \pm 1.91 \mathrm{a}$ & $5 \pm 2.04 b$ & $\pm 1.04 a$ & $0.5 \mathrm{a}$ & $10.02 \pm 1.58 \mathrm{a}$ & $1.05 \mathrm{a}$ \\
\hline $\mathrm{CM} / \mathrm{EN} / \mathrm{DW} / 20$ & $133.84 \pm 2.85 a$ & $130.64 \pm 2.48 b$ & $20.84 \pm 1.64 \mathrm{a}$ & $18.06 \pm 2.08 \mathrm{~b}$ & $20.35 \pm 1.68 \mathrm{a}$ & $17.51 \pm 2.18 b$ & $3 \pm 1.22 \mathrm{a}$ & $3.21 \pm 1.02 \mathrm{a}$ & $9.81 \pm 1.68 \mathrm{a}$ & $10.61 \pm 1.36 \mathrm{a}$ \\
\hline $\mathrm{CM} / \mathrm{EN} / \mathrm{DW} / 12$ & $134.87 \pm 3.08 \mathrm{a}$ & $130.95 \pm 2.94 b$ & $20.33 \pm 1.71 \mathrm{a}$ & $18.92 \pm 2.11 \mathrm{~b}$ & $20.45 \pm 1.92 \mathrm{a}$ & $18.88 \pm 2.45 b$ & $3.08 \pm 1.35 \mathrm{a}$ & $3.04 \pm 0.65 a$ & $8.69 \pm 2.15 a$ & $9.34 \pm 1.84 \mathrm{a}$ \\
\hline CM/EN/DW/27 & $134.21 \pm 3.6 \mathrm{a}$ & $130.93 \pm 2.81 b$ & $20.44 \pm 1.95 a$ & $17.32 \pm 2.14 b$ & $20.45 \pm 1.84 \mathrm{a}$ & $17.85 \pm 1.17 b$ & $2.84 \pm 1.37 \mathrm{a}$ & $3.1 \pm 0.48 \mathrm{a}$ & $8.78 \pm 2.83 a$ & $9.84 \pm 1.92 \mathrm{a}$ \\
\hline $\mathrm{CM} / \mathrm{EN} / \mathrm{DW} / 7$ & $135 \pm 2.84 \mathrm{a}$ & $130.84 \pm 2.55 b$ & $20.67 \pm 1.88 \mathrm{a}$ & $17.86 \pm 1.92 b$ & $21.13 \pm 1.62 \mathrm{a}$ & $17.86 \pm 2.14 \mathrm{~b}$ & $2.76 \pm 1.92 \mathrm{a}$ & $2.95 \pm 1.62 \mathrm{a}$ & $9.88 \pm 1.86 a$ & $10.05 \pm 1.02 \mathrm{a}$ \\
\hline CM/EN/DW/01 & $134.02 \pm 3.06 \mathrm{a}$ & $130.78 \pm 2.48 b$ & $20.62 \pm 1.64 \mathrm{a}$ & $17.82 \pm 1.62 b$ & $20.93 \pm 1.93 \mathrm{a}$ & $17.64 \pm 1.89 \mathrm{~b}$ & $2.87 \pm 1.33 \mathrm{a}$ & $3.07 \pm 0.47 \mathrm{a}$ & $10.14 \pm 1.24 \mathrm{a}$ & $10.57 \pm 1.32 \mathrm{a}$ \\
\hline
\end{tabular}

Averages followed by the same letter in the same column are not different significantly with $\mathrm{P}<0.05$ (Test of Duncan).

after storage period. For the ash and humidity, any significant $(p>0.05)$ different between the Bambara groundnut varieties and storage were observed.

The change of the gel strength, the water absorption capacity and the solubility index found to be due to the modification of the grains parameters such as $\mathrm{pH}$ and certain minerals such as calcium, by weevils droppings, and even by the presence of eggs in the middle (Goudoum et al., 2012). Schmidt et al. (1978) studies revealed a $\mathrm{pH}$ above 7.5 to 8.0 reduces the firmness of gels and increases from the addition of $\mathrm{CaCl} 2$ (with maximum firmness to 0.0011 million in $\mathrm{CaCl} 2$ ). This $\mathrm{pH}$ range, according to these authors decreases, however elasticity and water absorption capacity of the gels. Similarly, Dunkerly \& Zadow (1984) showed that the firmness of the gels increases with decreasing the content of free calcium ions, ended the presence of disulfide reducing agents inhibits gelation (Hillier et al., 1980). Furthermore, the work of Noomhorm et al. (1997) on wheat, show an increase in the water absorption capacity with the storage period. According Badifu (2001), the addition of $\mathrm{NaCl}$ up to a certain threshold increases the water absorption capacity. Similar results of Bambara groundnut were detected by Eltayeb et al. (2011) who showed that water absorption capacity and solubility index were high due to higher polar acid residues of proteins which have an affinity for water molecule. Study done by Ijarotimi et al. (2009) shown that, Bambara groundnut has a good functional properties that may be used as substitute for mane commercial weaning formula.

\section{Conclusion}

It could be concluded that varieties from Far-North, chemical composition and functional properties affected the resistance to insect attacks, and contribute to the stability of grains. Chemical composition and the functional properties of Bambara groundnut make theses seed an ideal raw leguminous for human nutritional supplementation. The Bambara groundnuts having a light color are the most attacked and have good nutritional and functional potential.

\section{References}

Adebowale, K. O., Olu-Owolabi, B. I., Olawumi, E., \& Lawal, O. S. (2005). Functional properties of native, physically and chemical modified breadfruit (Artocarpus artillis) starch. Industrial Crops and Products, 21(3), 343-351. http://dx.doi.org/10.1016/j.indcrop.2004.05.002. 
Amevoin, K., Glitho, I. A., Monge, J. P., \& Huignard, J. (2005). Why Callosobruchus rhodesianus causes limited damage during storage of cowpea seed in a tropical humid zone in Togo. Entomologia Experimentalis et Applicata, 166(3), 175-182. http://dx.doi. org/10.1111/j.1570-7458.2005.00321.x.

Anderson, R. A., Conway, F. F., Pfeifer, V. F., \& Griffin, E. L. (1969). Rolland extrusion-cooking of grain sorghum grits. Cereal Sciences Today, 14, 372-380.

Aremu, M. O., Olaofe, O., \& Akintayo, E. T. (2006). Chemical composition and physicochemical characteristics ot txo varieties of Bambara groundnut (Vigna subterrenea) flours. Journal of Applied Sciences, 6(9), 1900-1903. http://dx.doi.org/10.3923/jas.2006.1900.1903.

Association of Official Analytical Chemists - AOAC. (1990). Official methods of analysis (15th ed., Vol. 2). Washington: AOAC.

Association of Official Analytical Chemists - AOAC. (2000). Official methods of analysis of the Association of Official Analytical Chemists (17th ed., pp. 2201-3301). Arlington: AOAC.

Atiku, A. A., Aviara, N. A., \& Haque, M. A. (2004). Performance evaluation of Bambara groundnut Sheller. Agricultural Engineering International: the CIGR Journal of Scientific Research and Development, 6(4), 1-18.

Ayamdoo, A. J., Demuyakor, B., Badii, K. B., \& Sowley, E. N. K. (2013). Storage Systems For Bambara Groundnut (Vigna Subterranean) And Their Implications For Bruchid Pest Management In TalensiNabdam District, Upper East Region, Ghana. International Journal of Scientific \& Technology Research, 2(2), 181-186.

Azam-Ali, S. N., Sesay, A., Karikari, K. S., Massawe, F. J., AguilarManjarrez, J., Bannayan, M., \& Hampson, K. J. (2001). Assessing the potential of an underutilized crop - a case study using bambara groundnut. Experimental Agriculture, 37(04), 433-472. http://dx.doi. org/10.1017/S0014479701000412.

Badifu, G. I. O. (2001). Effect of processing on proximate composition, antinutritional and toxic contents of kernels from Cucurbitaceae species grown in Nigeria. Journal of Food Composition and Analysis, 14(2), 153-166. http://dx.doi.org/10.1006/jfca.2000.0964.

Barimalaa, I. S., Achinewhu, S. C., Yibutana, I., \& Amadi, E. N. (1994). Studies on the solid substrate fermentation of Bambara groundnut. Science Food Agriculture, 66(4), 443-453. http://dx.doi.org/10.1002/ jsfa.2740660404.

Beti, J. A., Phillips, T. W., \& Smalley, E. B. (1995). Effects of maize weevils (Coleoptera: Curculionidae) on production of aflatoxin $\mathrm{B}_{1}$ by A. flavus in stored corn. Journal of Economic Entomology, 6(6), 1776-17782. http://dx.doi.org/10.1093/jee/88.6.1776. PMid:8537546.

Brabin, B. J., \& Coulter, J. B. S. (2003). Nutrition associated disease. In GC Cook \& AL Zumla. Manson's tropical diseases (pp. 561-580). London: Saunders.

Cagampang, G. B., Perez, C. M., \& Juliano, B. O. (1973). A gel consisting test for eating quality of rice. Journal of the Science of Food and Agriculture, 24(12), 1589-1594. http://dx.doi.org/10.1002/ jsfa.2740241214. PMid:4771843.

Chiwendu, N. J. (2007). Chemical composition of four varieties of ground bean (Kerstingiella geocarpa). Journal Agricultural and Food Environmental Extension, 6(2), 63-74.

Chukwujindu, B., Chinedu, F. A., \& Chukwujindu, S. E. (2013). Evaluation of some accessions of Bambara groundnut (Vigna subterranean L. Verdc) for resistance to bruchid infestation, based on grain source and seed coat colour. Journal of Plant Protection Research, 53(3), 210-2014.

Costa, R. R., De Sousa, A. H., Faroni, L. R. D.A., Dhingra, O. D., \& Pimentel, M. A. G. (2006). Toxicity of mustard essential oil to larvae and pupas of Sitophilus zeamais (Coleoptera: Curculionidae). In
Proceedings of the 9th International Working Conference on Stored Product Protection. Campinas, São Paulo.

Dunkerly, J. A., \& Zadow, J. G. (1984). The effect of calcium cysteine hydrochloride on the firmness of heat coagula formed cheddar whey protein concentrates. Australian Journal of Dairy Technology, 39, 44-47.

Eltayeb, A. R. S. M., Ali, O. A., Abou-Arab, A. A., \& Abu-Salem, F. M. (2011). Chemical composition and functional properties of flour and protein isolate extracted from Bambara groundnut (Vigna subterranean). African Journal of Food Sciences, 5(2), 82-90.

Fisher, E. H. \& Stein, E. A. (1961). DNS colorimetric determination of available carbohydrates in foods. Biochemical Preparations, 8, 30-37.

Food and Agriculture Organization of the United Nations - FAO. (1993). Le maïs dans la nutrition humaine (174 p.). Rome: FAO ONU pour l'alimentation et l'agriculture.

Goudoum, A., Ngamo Tinkeu, L. S., Ngasoum, M. B., \& Mbofung, C. M. (2012). Variation in technological and nutritional parameters of maize treated with essential oils during storage. African Journal of Food Science, 6(2), 34-40. http://dx.doi.org/10.5897/AJFS111.198.

Hillier, R. M., Lyster, R. L. J., \& Cheeseman, G. C. (1980). Gelification of reconstituted whey powder by heat. Journal of the Science of Food and Agriculture, 31(11), 1152-1157. http://dx.doi.org/10.1002/ jsfa.2740311105.

Ijarotimi, O. S., Oyewo, M. T., \& Oladji, B. S. (2009). Chemical, functional and sensory properties of roasted Bambara groundnut (Vigna subterranean L. Verdc) and cooking banana (Musa spp., ABB genome) weaning diet. African Journal of Food Science, 3(5), 139-146.

International Bureau for Analytical Studies - BIPEA. (1978). Collection of analysis methods from Europeans Community (pp. 29-31). Paris: BIPEA.

Kahane, R., Hodgkin, T., Jaenicke, H., Hoogendoorn, C., Hermann, M., (Dyno) Keatinge, J. D. H., d'Arros Hughes, J., Padulosi, S., \& Looney, N. (2013). Agrobiodiversity for food security, health and income. Agronomy for Sustainable Development, 33(4), 671-693. http://dx.doi.org/10.1007/s13593-013-0147-8.

Kellouche, A., \& Soltan, N. (2004). Activité biologique des poudres de cinq plantes et de l'huile essentielle d'une d'entre elles sur Callosobruchus maculatus (F.). International Journal of Tropical Insect Science, 24(1), 184-191.

Mayes, S., Massawe, F. J., Alderson, P. G., Roberts, J. A., Azam-Ali, S. N., \& Hermann, M. (2012). The potential for underutilized crops to improve security of food production. Journal of Experimental Botany, 63(3), 1075-1079. http://dx.doi.org/10.1093/jxb/err396. PMid:22131158.

National Research Council. (2006). Lost crops of Africa (Vol. 2). Washington: Academies Press. Retrieved from http://www.nap.edu/ openbook.php?record_id=11763 on 22/06/2012.NRC

Ngamo, T. L. S., Goudoum, A., Djakissam, W., Ayike Evele, N., Madou, C., \& Marcus Zilbinkaye, M. (2016). Les bruches du voandzou Vigna subterranea (L.) et les outils de protection post récolte dans le Nord du Cameroun. Entomologie faunistique - Faunistic Entomology, 69. In press. Retrieved from http://popups.ulg.ac.be/2030-6318/index. php?id=3484.

Noomhorm, A., Kongseree, N., \& Apintanapong, N. (1997). Effect of ageing on the quality of glutinous rice crackers. Cereal Chemistry, 74(1), 12-15. http://dx.doi.org/10.1094/CCHEM.1997.74.1.12.

Okafor, P. N., \& Nwabuko, C. U. (2003). Cyanide, nitrates and nitrite contents of livestock feeds in Umuahia, Nigeria. Biokemistri, 14, 57-63.

Olanipekun, B. F., Otunola, E. T., Adejuyitan, J. A., \& Adeyanju, J. A. (2012). Proximate and fatty acid composition of Bambara groundnut 
(Voandzeia subterranean L. Thouars) as influenced by fermentation with a combination of Rhizopus oligosporus and R.nigricans. Transnational Journal of Science and Technology, 2(9), 77-87.

Park, S. H., Arthur, F. H., Scott, R. B., \& Schober, T. J. (2008). Impact of differing population levels of Rhyzopertha dominica (F.) on milling and physicochemical properties of sorghum kernel and flour. Journal of Stored Products Research, 44(4), 322-327. http:// dx.doi.org/10.1016/j.jspr.2008.02.008.

Schmidt, R. H., Illingworth, B. L., \& Ahmed, M. (1978). Heat-induce gelation of peanut protein/whey protein blends. Journal of Food
Science, 43(2), 613-621. http://dx.doi.org/10.1111/j.1365-2621.1978. tb02366.x.

World Health Organization - WHO. (2002). World health report. Geneva: WHO.

Yusuf, A. A., Ayedun, H., \& Sanni, L. O. (2008). Chemical composition and function properties of raw and roasted Nigerian benniseed (Sesamum indicum) and Bambara groundnut (Vigna subterranean). Food Chemistry, 111(2), 277-282. http://dx.doi.org/10.1016/j. foodchem.2007.12.014. PMid:26047423. 